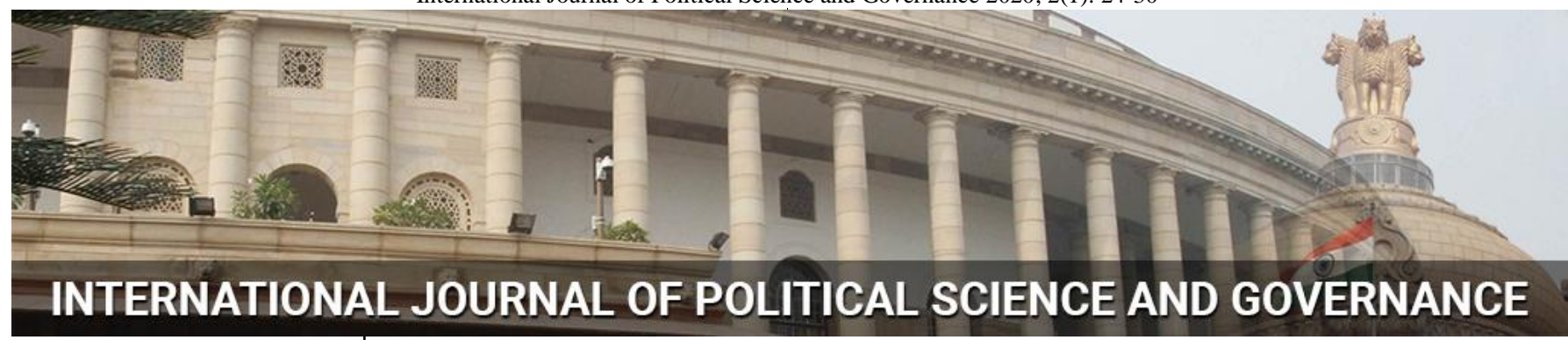

E-ISSN: 2664-603X P-ISSN: 2664-6021 IJPSG 2020; 2(1): xx-xx Received: 12-11-2019 Accepted: 15-12-2019

Gwladys Nicimbikije Faculty of Political and Social Sciences, Parahyangan Catholic University, Ciumbuleuit, Bandung Indonesia
Corresponding Author: Gwladys Nicimbikije Faculty of Political and Social

Sciences, Parahyangan Catholic University, Ciumbuleuit, Bandung Indonesia

\section{Speech over! Securitization in acts: National economic security}

\section{Gwladys Nicimbikije}

DOI: https://doi.org/10.33545/26646021.2020.v2.i1a.29

\begin{abstract}
In order to ensure the practicalities of the securitization from its 'speech to acts' within new sectors and new security, the author feels motivated to pose the following question: how should national economic security respond to the imminent new national threat by considering the premise and the impact of national stability? The author holds the view that the origin of broadening the security derives its source form its continuous studies besides its awareness that a state's threat does not always come necessary from outside but is likely to happen within the state and cause damage on the same scale as traditional threats. Evidence is provided through various examples while the analysis is based on theories related to critical security studies and securitization as speech and even more in acts by widening and deepening security through economic security as a new threat in a new sector.
\end{abstract}

Keywords: Critical Security studies, economic security, corruption, (social or ecological) threats

\section{Introduction}

Security being substantial to a nation-state as well as to its citizens, this study aims to outline the effect of inattention to national threat that results from the little criticism of the security that is insufficiently broadened, nor is it deepened adequately. Securitization layers overlap with state functioning aspects that appear (a) vital when the first and foremost national interest of state is equivalent to its state sovereignty protection; (b) very important when citizens' economic wealth occurs as the state priority besides preoccupation; (c) diplomatically important when considering that national security is linked with international security, hence leading to the state's choice of participating in overall world peace. Security has therefore a multidimensional apprehension on the one hand while on the other its strategic studies lead to dynamics of progress of a desired 'security.' Like any science, Security Studies respond differently due to inter-combining with other natural sciences. Epistemology being a science related to the nature of knowledge enables the security or during its process of securitization to use logic. In the same schemes, Ontology being the science related to nature of being enables the security to be responded in cognitive ways that both lead to normative implications of traditional (realist) approaches or use of tools where its use of force results from state threat and hence subject to coercive measures in order to achieve the security. (Walt, 1991) ${ }^{[1]}$ As a response to the vital national state interest.

Secondly, the citizens' economic wealth is tremendously fundamental and the core of the state process operating mechanism that is only comprised with wealth but also with other components namely, health, education, household income through state monetary and fiscal policy in order to enable consumption, trade, food and other social services as well as state governance within dynamics of politics. Security is thus moving beyond the speech or theories to shift to acts or practicalities in order to result to 'absence of threat' as new security within new sector(s). (Browning and McDonald, 2011) ${ }^{[2]}$. Thirdly, the dynamics of politics within regional and international dimension of the security besides the national one enables the state to globally respond to security concerns. However, it will have less meaning when the nation-state decides to tackle the global security through world war without having accomplished or regulated the wealth of their citizens. It is clear that the new sector of threat to be addressed is not related only to the outsider in order to respond to traditional security but also to the inside threat. To this point what is security today? For what purpose? 
Starting from the latter -as the former will be discoursed in the upcoming section-, the multi dimensionality of the security enables security to be understood starting from state security and going deeper in order to (a) alleviate vulnerability of threats by responding to national interest/sovereignty in a way of local self-control and selfefficiency as principle that is going to be termed 'new welfare of state' referring to national economic security as the core of this study since the impact of new threats affect it; (b) reprieve new threats in order to strengthen human security referring to human capital as extremely important for both the actors of the security and the labour for increasing the economy; (c) over-view the former security (traditional or realist), which brings the reason for widening the securitization and incorporating new security as a sufficient reason to shift from traditional security to nontraditional security by deepening economic security and one of its effects once this threat is neglected; (d) allow dynamics of politics through its progress and implementation to widen and deepen economic security.

\subsection{Materials and Methods}

The reason for deepening and widening security has therefore led to the answer: Which dynamics of political security systems could emphasize democratic governance to set the deepening and the broadening of security into joinedup approaches and oriented one in order to secure citizens from threats such as corruption, inequality, poverty and ecological matters?

The following hypothesis will guide the author all the way through: Since National Economic Security (economic growth) overlaps with citizens' wealth, developing a national security policy could reinforce speech to acts and enable (economic) emancipation of the citizens. Moreover, process-tracing methodology, critical 'theory' in security studies with the constructivism approach as well as inductive reasoning have been applied to this purpose.

\section{Securitization as speech-act contextualized in economic security}

Security studies being a science that falls under International Relations and its implementation taking place in societies besides the rapid spread of technology, its evolvement is a remarkable unlimited view through 'securitization' or the 'Copenhagen School framework task/thoughts'. The broadness of securitization results from the approaches (constructivism, post-constructivism and critical security studies) utilized I the unique traditional theory about security to the advantage of multi-security. In other words, harnessing (Neo) Realist theories on their home/traditional security turf has led to security wideness or broadness. (Williams, 2003) ${ }^{[3]}$ and (Huysmans, 1997: 186) ${ }^{[4]}$. Security has become broader and its approach around the 1990s was practised within development and security policy. To put it in another way, the evolvement of security has shifted from theories in order to transform itself into the security sector reform layer. (Sedra, 2010) [5] insists on arguing that the security sector reform layer enables issues to be addressed and deepened within the security role in the political and economic lives of countries. The apprehension of security differs considerably where it appears to be happening in the South on the one hand while on the other, all effort and approaches are made in the North hence the emphasis on its importance and necessity for the global
North. The notion of democratic (good) governance in the politics of dynamics within the security enables institutions like the Organization of Economic for Cooperation and Development- OECD to play a substantial role since in politics various actors are observed. As a result, this substantiality or preponderant role played in various ways through broadening and widening security by its increasingly criticism approach due to the Copenhagen School theories has branded the securitization theory as 'sociologically untenable'. (McSweeny, 1996; 1999) ${ }^{[6]}$.

Furthermore (Risse, 2000) [7] considers 'speech-act' to involve two aspects where one aspect is related to political argumentation in order to formulate theories and discursive legitimation, or criticism to enable its securitization. It is termed 'speech of securitization.' Another aspect is that there are security practices or actions that lead to transformation and ethics according to constructivist theory due to security deepening. It is termed 'new security deepened in the new sector.' For instance, economic security is analyzed where actions and measures are considered within policies and taken into account in order to prevent oneself from food shortage, to reprieve poverty, reduce or eliminate air polluted, extra pesticides, irrigation issues, water scarcity, land conflict, chemical disasters, infectious diseases and others, in at the least mind of the author. It is clear that all these various aspects have an effect on the national economy, therefore emergence of linking it to human security such as health human capital, or human rights for labourers. Securitization theories enable the analysis within various approaches and measures where threats are recognized, deepened, and addressed, which facilitates issues to become 'securitized.'

$$
\text { Speech }=a_{0}+\sum_{n=1}^{\infty} \text { (Securitization theories within diverse thoughts) }
$$

\section{$a_{0:}$ (Neo) realist security}

$$
\text { Act }=\text { Analysis }+\mathrm{SPP}+\sum_{n=1}^{\infty}(\mathrm{dns} * \text { threat } 1+\mathrm{dns} * \text { threat } 2+\cdots \text { Threat } n \text { widened })
$$

SPP: Security Policy Process as national security in the economic realm

\section{dns: Deepening New Security in any sector}

In addition to this, international security is linked with national security due to the fact that security is widened, thus it is imperative to underscore that speech-act securitization is an impetus to its practicalities. What is security today and how could national economic security be apprehended? Simply as the absence of threat which preceded the survival of these threats. (ICRC, 2015) ${ }^{[8]}$ defines economic security as the absence of threats that allows individuals (households) or societies to cover sustainably minimum needs with dignity. However, the minimum need varies subjectively according to one's expenditure and living standard in all aspects food, health care, education, clothing, and clean water. This definition is one example of broadened and deepened security in the Economic realm according to the Copenhagen School as 3 aspects are considered in security studies, namely (a) Broadening security; (b) Security in societies; and (c) Securitization. Their applicability results in the security being deepened in 4 layers: (i) process and practical; (ii) defining threat or security properly without mixing up 
security concerns with political issues; (iii) multidimensionality of security or multi security where the central actor remains the state; (iv) the practical logic of security that goes beyond the military realm. Constructivism on the other side within dominant constructivism has stimulated innovative approaches. These approaches are termed 'critical constructivism' that eases a path to security studies by playing a preponderant role in structure which is termed 'normative' and resources that allow actors of security in peace stability. Here peace stability can be considered a national security whose absence is a threat and which national security has an effect on the national economic security resulting from deepening and widening the security. (Macleod, 2004) ${ }^{[9]}$.

The practicality of security, economic policy for instance is meaningful when it is focused on redefining policies as political governmental agenda in order to address citizens' needs first and foremost when one is able to access to the marketplace buying or selling goods and services rather than redefining the concept of security itself. If the monetary and fiscal policies fail to respond to its raison d'être such as money supply regulation, stabilizing inflation, interest rate both domestic and foreign exchange or making appropriate decisions in macroeconomics state is far safer from threat such as, hunger, increase of food price, unemployment, depreciation of the currency, less access to education, rise of inequality, social conflict due to mismanagement of the ecosystem and, less access to health services, so the government is unable to respond to epidemics occurring, neither having control over illegal environment overexploitation, human rights, social injustice that lead to bribery and illegal activities that arise from there: drug traffic besides the Neo (realist) security concern that is susceptible to emerge due to weak governance of a country invasion likely to happen. (Baldwin, 1997) ${ }^{[10]}$ highlights that after the securitization theories its impact on the practical aspect is required, which needs security to be evaluated through security policy. One way is through critical constructivism with its insistence on structures or 'normative constructivism'. Security policy needs to assess who is subjected to threat within values and ethical discourse that result in protecting individuals or (specific) group of people, for instance children or certain genders. The second way is to quantify the magnitude/scale of the presence of threat with much focus to its consequences rather than the causative threat itself.

These two points mentioned above require looking for a tool in order to assess the securitization in acts or the dynamics of political security systems that enable the democratic governance deepen and broaden national economic security in following questions analysis according to (Baldwin, 1997) ${ }^{[11]}$ since social sciences and politics have a straight effect on societies that fall under nation-states: (a) 'Of what is this instance?' this question could be reformulated as 'Why is the threat occurring?' Successful policy evaluation digs deeper in order to found out about the cause and the causative. For instance, the cause of the (economic) threat will facilitate security assessment and its progress, hence regularly mid-evaluation will help to achieve the national (economic) security slightly freedom from threats. (b) Security policy is both solution and measurement of threat. Therefore, if one policy should be distinguished from others while analyzing security due to different threats resulting from new security and a new sector, referring to the multi- security national security policy is in addition to preferable, and sub-policies to align special security treats. National Economic Security is still the core of state in steering the economy, social improvement and politics governance. (c) Distortion of scholars' views from diverse schools should be harmonized instead, in order to extend security thoughts from critical constructivism, Post constructivism, the Copenhagen School and others on its evaluation within indicators. Decades ago, (Wolfers, 1952) ${ }^{[12]}$ highlighted the fundamentality of security as objectively to measure the absence of threats in order to acquire values and as subjectively to measure the absence of the fear that those acquired values are susceptible to be attacked. In sum, the practicality of national economic security resides in its pecuniary means resources allocated as well as to enabling it to the benefit of potable water, unpolluted atmosphere, food availability, and social security in order to access to health services, education and others in the mind of the author.

\section{Economic threat vs Primacy of economic security}

Economics is a social science field that considers decisionmaking within policies in marketplace regulation. International relations being a science that considers the dynamics of politics takes into account the economy with other nations for both their global and domestic dimension of trading. This being so, International political economy will add the market and politics for the economic regulation. The two strengthen the economy. Therefore, the economy finds its foundation of national economic security which if not taking into account an imminent threat is likely to affect the apparatus of the government within its dynamics of political security systems and even, the global politics dynamics systemic context. (Ronis, 2011) ${ }^{[13]}$.

Furthermore, the problem-(delay) solving apparatus of the government according to (Ronis, 2011) ${ }^{[14]}$ endangers the economy and the whole national (economic) power since the threats could appear in the form of debt, government policy-making decisions, weak governance, industrial capability mechanism, energy, science, technology, human capital, clean water, breathable air, security, agriculture, deregulation of climate, inefficiency of water management that leads to scarcity, pollution and others in the mind of the author. National economic security founds its power and its utterance of securitization theories (speech) in taking into account broadening and deepening security through national security policy. The forcefulness of the latter in security studies is not only its power consideration in politics arena but also its efficacious in societies hence the absence of national economic threat menace. The outcome of national economic security results from its willingness to widen, broaden and deepen (national economic) security even more, to solve problems in societies. In account of that, the concept of new security, for instance being broadened and deepened and the securitization theories is the 'good side of security' since its dynamics of progress and security policy reinforce the logic of security in order to achieve a desired national (economic) security. For instance, the migration to alternative energy sources lessens global warming then it a way to mitigate climate change. Providing low cost of energy resource not only increase social living for households but also yield to economy. Due to energy efficiency being widespread, the US expects a yield of gross energy savings of up to USD 1.2 trillion. Energy becomes a form of national security. (Ronis, 2011) ${ }^{[15]}$. 
Critical theory in security studies details the complexity of security as a phenomenon thus shows itself practical in terms of addressing matters that endanger/threaten the security. For instance, the safety of processing chemicals industries needs to be taken into consideration as they can be a health threat for national economic security, in case of the Bhopal tragedy in India (1984) that killed over 2,000 people besides tens of thousands being injured, and resulted in soil contaminated with disease such as cancer and deficient disease until today. The industrial disaster that caused an explosion at the Liquid Petroleum Gas Plant in Mexico City (1984) killed more than 600 people and injured 7,000. The firefighting efforts aside Sandoz Warehouse in Switzerland (1986) resulted in releasing chemicals and pesticide and caused aquatic life destruction, and fish were banned for consumption within a time period of 6 months. The Exxon Valdez oil spill disaster released a much higher volume of about 10.8 million US gallons and affected aquatic biodiversity in Alaska (1989) more than Deeperwater Horizon incident in the Gulf of Mexico, 2010. (NESS, 2015) ${ }^{[16]}$.

\subsection{Critical theory of security and social matters}

The research area of critical security studies according to Peoples and Williams (2010) ${ }^{[17]}$ is complex which makes it difficult to find a proper definition of it. Its inability to find what security is and what it means makes it more critical, thus polemic. 'Critical' then becomes each point of view and whose view's approach intends critically to assess modern matters or the matters of the present time. For instance, one's point of view on global warming where his understanding leads to a practical dimension. In other words, by putting down the damage it causes one is referring to the threats that endangers humans where one directs oneself to the practicality of the state in terms of addressing solutions. 'Critical' theory to security studies, born to address is the threats-, is therefore capital since derives its source from 'national security' where the state is constantly hunting in order to find a way to prevent/protect oneself from military threats, or state invasion. Arnold Wolfers (1952) ${ }^{[18]}$ in the 'traditional' realist approach of the security considers it as an 'ambiguous symbol' due to its controversial multiple apprehensions of the notion 'security.'

Among these ambiguities of the apprehension of 'security' appears what is means to be secure or which needs to secure, the causes of insecurity in the intention to address these menaces of insecurity, and who or what the concept of security should apply to or in other words identify subjects and objects in order to allow the applicability onto them. From the assumption of the contested notion of 'security' (Baldwin, 1997) ${ }^{[19]}$ or the incongruity of the lack of a common definition despite its shared imperativeness to be applied, that the critical security studies find a breach to make a rational decision about security within judgements by discriminating to the advantage of crucial or critical approaches to security based to their 'intellectual activity' in order to give orientation of the needs to secure. Peoples and Williams (2010) ${ }^{[20]}$. It is in this scheme that Keith Krause and Michael C. Williams (1997) ${ }^{[21]}$ reiterated that the term critical to security studies implies orientation of the realm of security studies followed by its theoretical perspectives, therefore giving explanations thus becoming assessed through their tasks. In other words, critical security studies are meant to be practical rather than theoretical such as making decision in order to achieve a purpose. Critical security studies, therefore, appear to be making radical changes. Within this 'orientation' of critical security studies, a desired outcome is expected throughout change by taking into account the causes of insecurity and making practical decisions onto these so that the 'subjects' or 'whom' and the 'objects' or 'what' benefit the change made by critical security studies through explanation, analysis and assessment.

\subsection{Cases in perspectives mapped by critical security studies}

Critical security studies are mapped into three dimensions which enable their practicality on terrain. (i) its reject of apprehending security in the 'traditional' perspectives; (ii) its objective, orientation that results in a trajectory of development in the realm of critical security; (iii) its evaluation has meaning in geographical area of operating its 'thought'. This section intends to analyse threats that have an effect on the overall state's economy. The analysis of these threats is expecting an outcome that is a change. At the same time, analysis goes with actions, interactions and perceptions. In order to achieve change one needs to detect the causes and understand them. Therefore, what causes poverty or corruption to happen is similar to how to secure citizens from these threats. Due to the behaviour, the emergence of conflict brings interest whose numerous actions are subjects whether to the insecurity happening or the security happening in case of addressing the former. At the end, one needs to install or prescribe the norms. It is termed respectively 'regulative norms' the behaviour that causes norms, 'constitutive norms' interest of causing the threat or the interest in preserving the ecology whereas 'prescriptive norms' calls for the respect of the norm in the society. Mcglinchey et al. (2017) ${ }^{[22]}$. They keep on explaining how all these norms range between material structure and ideational structure which lead to reality as itself under construction which gives an opportunity to change as social norms are capital to constructivism. Therefore, this section will use the method of constructivism in order to give meaning to acts rather than speech driven by the orientation of change. It is the logic of appropriateness. The Southeast Asian Country-Indonesia for example, among other regions in the same locality have faced an incredibly quick growth compared with other regions of the world. Many of the motives for success were the intervention of the government, opening up to foreign trade, reaping the global finance and attracting investors. (Wade, 1990) ${ }^{[23]}$. The peak dropped when the 1997 crisis hit after a rich decade of jacked up economic rates to the extent that outsider started questioning whether the growth was not due to the accumulation of factors rather than total factors of productivity growth. Vial and Hanoteau (2009) ${ }^{[24]}$ highlight that 'cronyism' and corruption are the foundation of a strong relationship-based system though such systems are at peril, especially when financial markets open, which anticipate a crisis of confidence. These perilous 'relationship-based systems built on enforced poor contracts and capital scarce' were interesting subjects of study, mainly after the financial crisis of 1997 hit Southeast Asia and found themselves under development economics models which resulted in breakdown of the roots of their economies. (Claessens, Djankov, Fan, \& Lang, 1998a, 1998b, 1998c, 1998d; 
Prowse, 1998; Rajan \& Zingales, 1998) [25]. Rajan and Zingales (1998, p.559) [26] added the Southeast Asian economies relationship-based systems rely on the short-term contracts of arm's-length investors' capital in order to limit the risk associated with the misallocation of capital. They highlighted too how once these arm's-length investors pull out, the system automatically collapses. Indonesia is among these crony capitalist systems that experienced increased economic growth rate over the 1970s and suffered similarly to date from the 1997 crisis under General Suharto's rule (996-98) where output aggregate growth of the manufacturing sector reached $9.30 \%$ annually and the total factors of production growth were between $2.70 \%$ (Aswicahyono, 1998) ${ }^{[27]}$, to $2.80 \%$ (Timmer, 1999) ${ }^{[28]}$ to $3.54 \%$ (Vial, 2006) ${ }^{[29]}$. Meanwhile at the micro-level, the manufacturing plant's average annual output growth rate amounted $4.60 \%$, within an average labor productivity growth of $2.40 \%$. Cronyism and corruption are prevalent and depict the Asian paradox, though they do not necessary impede business functioning. (Rakan \& Zingales, 1998) ${ }^{[30]}$. (Data source excerpted from Vial and Hanoteau (2009) [31] in Corruption, Manufacturing Plant Growth, and the Asian Paradox: Indonesian Evidence) Except in Asia, many other countries do not survive such a degree of corruption, as explained above. They keep afloat holding, back reversion and regression instead, which is understandable as corruption is considered detrimental to investment and growth at the macro-level. (With the empirical approach (Mauro, 1995; Méon \& Sekkat, 2005; Wei, 2000) and theoretical arguments, see (Bardhan, 1997; Rose-Ackerman, 1999) ${ }^{[32]}$. One may assume that corruption is anchored in Asian culture over a decade to the extent that it does not hamper business. (Kaufmann and Wei, 1999, p. 10) ${ }^{[33]}$. For instance, Indonesia under President Suharto scored 1.5 in the rage of 0 to 10 on the corruption index in 1980-83 (The Economist Intelligence Unit, former Business International) and is ranked the most corrupted country despite its continuous economic growth. In Indonesia, the bribe rate contributes to a significant portion of the average manufacturing plant output growth (See the calculation of Vial and Hanoteau, 2009) [34]. Similarly, corruption affecting the manufacturing plant output and labour productivity growth are is correlated positively. (Vial and Hanoteau, 2009) ${ }^{[35]}$. However, in African states corruption always has a negative impact on business growth due to political instability and economy shrinking. (See the calculation by Vial and Hanoteau, 2009) ${ }^{[36]}$. However, even though in Indonesia (including other Asian countries such as China, India) corruption seem to contribute to economic growth, it does not go without consequences for the local communities. In the survey conducted by the World Bank, over 3,000 Indonesian households in 2014 aimed at understanding how Indonesians perceive their country's deepening level of inequality, 9 Indonesians out of 10 Indonesian of adults, - trivialize (misperceive) the extent of inequality in their country-, locate themselves in the middle class income distribution bracket. In other words, the underprivileged and wealthy are alike and think they both experience the same average standard of living. Meanwhile, Oxfam's report about Indonesia's Inequality states that four men are estimated to be worth the same amount as the most underprivileged 100 million people while the richest $1 \%$ currently owns half of the country's wealth. (Hoy, 2017) ${ }^{[37]}$. With an almost 0.4 GNI of Indonesian communities' inequality, the welfare of the citizens is endangered, which will have repercussion sooner or later on the economic growth, thus posing a threat to national security.

In addition to inequality, other factors such as health and, storm-water runoff are threats and may impede the economic growth. Gaffield et al. (2003) ${ }^{[38]}$ explains how water treatment and, food production require protective measures to Indonesian the environment, otherwise illnesses are imminent and may constantly increase because of the deregulation of climate change. In more densely populated cities, floods, parking lots, chemical pollutants, sediment, and floating are threats to water because when it rains the water picks up all these pollutants found in storm-water and flowing to rivers and lakes which induce flooding in the city and increase ecological pollution of water and air. This is a major source of water quality in the US which affects humans' chronic diseases such as vectors for dengue hemorrhagic fever, the west Nile Virus and seafood decay and slows the recreational activities since beaches become polluted and face an increase of mosquitoes.

In the United States between 1991 and 2000, 123 documented outbreaks of water-borne illnesses in 30 states were linked to pathogens which amount USD 5,529 water bodies on one hand and on the other children, the elderly, pregnant women and the immunocompromised (20\% of the US population) are at the serious risk of illness and mortality from waterborne pathogens. Consequently, 99 million people in the US have gastrointestinal diseases each year whose cost amounts to billions of dollars among 6-40\% of these diseases are suspected to have been caused by contaminated drinking water. (Data source excerpter from Gaffield et al (2003) [39] in 'Public Health Effects of Inadequacy Managed Stormwater Runoff'). In Southeast Queensland, drought forms a major threat while industries including agriculture, manufacturing, mining, commercial and tourist enterprises all endow $62 \%$ of GDP and $68 \%$ of employment. Due to the water scarceness, the Southeast Queensland community has relied on rainfall collected over dams, then recharge the water to ground water aquifers to meet water needs. (QWC, 2008) ${ }^{[40]}$. Therefore, diversifying water needs and sources is an option in order to overcome the threat of water. The American cities have decided to turn into storm-water management through building blue-green storm-water infrastructure as the grey infrastructure causes problems of drainage, thus increasing diseases in communities. The Southeast Queensland increases social living by using storm-water use which results in supporting garden irrigation at 96\% (ARCWIS, 1999) ${ }^{[41]}, 95 \%$ supporting for toilet flushing, 68\% supporting laundry purposes, 50\% supporting personal washing and 29\% supporting storm-water as potable water. (DEC, 2006) ${ }^{42}$. (Data source excerpter from Philp et al (2008) ${ }^{[43]}$ in 'Review of Storm-water Harvesting Practices'). In sum, social threats, ecological threats, political threats, health threats impact negatively the economy. Thus threatens national security opposite to 'traditional' national security. The more the threat, the more the economy is affected and the more the state is trapped into poverty, and the more complex aggregate demand will respond to the consumption. This has an impact on the marketplace with leads to downward spiral economic decay and weak governance which bears consequences for the political dynamics of the security system, a vicious circle or trap of poverty. 


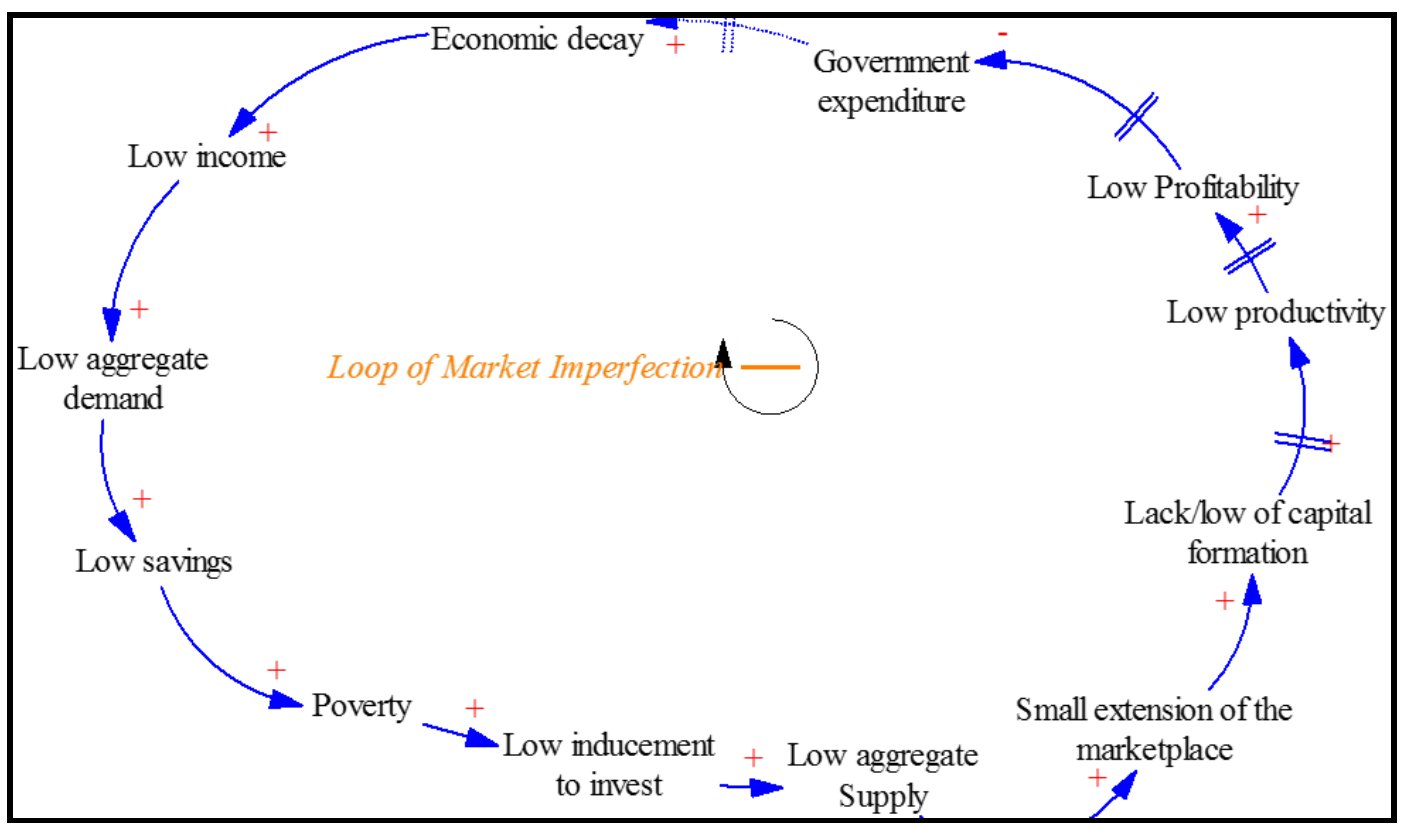

Source: Author

Fig 1: Causal loop modeling and simulation of Market imperfection as source of national economic threat

\section{Making a difference? Concluding comments}

Security studies have increased the degree of awareness of redefining the concept of security and the meaning of securitization through different theories which resulted from securitization as 'speech-act'. Broadening and widening the security have brought the author to emphasize the national economic security that encompasses diverse aspects such as the environment, health, public services, education, clean water and energy. The speech of the securitization should follow the act of the security itself which leads to its evaluation through a national security policy. The multisecurity allows the broadening and the deepening of the security on one side, and its imperative necessity to assess the new security or the actor. The Neo (realist) security is not the only threat that endangers a state through territory state invasion but also degradation of the environment, the use of toxins, uncontrolled technology, water scarcity, inefficient access to health service, and the preferable energy. Good governance and politics dynamics have an impact on the process of security implementation. Commodities in the economy are essential for its availability. Using renewable resources is another resource allocation in the economy for commodities as energy are not one, but it is possible to convert them into a resource allocation such as, conversion of solar power to electricity or water and wind. The new energy allows the state to be less dependent on the natural source such as coal or fossil fuel. Therefore, the availability of the electricity and its distribution equally enable the absence of threat.

Ronis (2011) [44] showed how knowledge is an important capital investment for a national economic security not to be neglected, as some measures need to be taken into account through the security policy during its process and the evaluation policy to prevent the occurrence of threat resulting from human errors that lead to environmental disaster. As seen above, this has an effect on health as well. Solutions like efficient use of natural resources or innovative ideas of renewing them are of extreme importance as they allow absence of threat in water scarcity or reduce global warming. The security policy could allow not only to assess the security but also lead another consistent innovation policy and protect new sectors. Therefore, one is prevented from new forms of threat. The evaluation policy should ensure the absence of fear of losing resources or value already acquired. Securitization indeed is an impetus/stimulus to national economic security besides the former Neo (realist) security.

In conclusion, the 'critical' in security studies has taking into consideration the 'referent object' in order to reach outcome of the security objective though explanatory steps, and assess by making judgements and decisions for change. Among others, it has analyzed corruption-related matters, inequality, water scarceness and drainage problems as well energy, both as matters that have an effect on social, political, ecological aspects all susceptible to regress the economy which becomes national security in the economic perspectives. 'Broadening' as a component has been tackled by addressing issues related to ecology, economic, or issues in the communities. The term 'deepening' is critical to security studies, considering the needs to secure. 'Normative' is critical to security studies based on the point of view or the stance of what has to be done by taking into account the analysis of the threats so that desired security is achieved. 'Security as a derivative concept' considers the critical approaches to security as a proper way in or a way itself to think critically about security for crucial purposes that indeed derive sources from an individual way of perceiving broadly how things work. The comparison has drawn between cultural Asian countries concerning corruption for endowing economic growth. In sum, the term critical in security studies has been guided by its proactivity and innovation to address issues for public awareness, increase of health and wealth and prevention from fearing to lose the already acquired security. It has achieved the acts of security, and thus the securitization for national (economic) security.

\section{References}

1. Anthon CM. Non-Traditional Security Studies: A Transnational Approach. London, California, New 
Delhi and Singapore. Sage, 2016.

2. Baldwin AD. The Concept of Security. Review of International Studies, British International Studies Association. 1997; 23:5-26.

3. Browning SC, McDonald M. The Future of Critical Security Studies: Ethics and the Politics of Security. European Journal of International Relations. 2011; 19(2):235-255. Doi: 10.1177/1354066111419538. London, Sage.

4. Gaffield et al. Public Health Effects of Inadequacy Managed Storm water Runoff. American Journal of Public Health. 2003; 93:9.

5. Hill C. Foreign Policy in The Twenty-First Century. Ed. 2. London, Palgrave: Macmillan Education, 2016.

6. Hoy C. The Study that Shows life is a Lot More Unequal. Than You (Probably) Think. Inequality by The Guardian retrieved from, 2017. https://amp.theguardian.com/inequality/2017/jun/06/stu dy-shows-life-is-a-lot-more-unequal-than-youprobably-think?_twitter_impression=true

7. Hudson MV. Foreign Policy Analysis: Classic and Contemporary Theory. Ed. 2. UK, Rowman and Littlefield, 2014.

8. Li HY, Tung PC, Chen YP. Storm water Management towards Water Supply at the Community Scale-A Case Study in Northern Taiwan. MDPI: Sustainability. 2017; 9:1206. doi: 10.3390/su 9071206.

9. Macleod A. Les Etudes de Sécurité: Du Constructivisme Dominant au Constructivisme Critique. Retrieved from Conflicts and cultures 54 Canadian Perspective: Approches Critiques de la Sécurité, 2004, 13-15. Doi : 10.4000/conflits.1506.

10. Mcglinchey S, Walters R, Scheinpflug C. International Relations Theory. England, Bristol: E-International Relations Publishing, 2017.

11. NESS A. Lessons Learned from Recent Process Safety Incidents. American Institute of Chemical Engineers, 2015.

12. Peoples C, Williams VN. Critical Security Studies: An Introduction, Ed. $2^{\text {nd }}$. New York, Routledge: Taylor and Francis Group, 2010.

13. Philp et al. Review of Storm-water Harvesting Practices. Urban Water Security Research Alliance Technical Report, 2008, 9

14. UNDP. Human Development Indices and Indicators: 2018 Statistical update. New York, 2018.

15. Ronis RS. Economic Security: Neglected Dimension of National Security? Washington D.C, National Defense University Press- NDU Press: Center for Strategic Conferencing Institute for National Strategic Studies, 2011.

16. Sedra M. The Future of Security Sector Reform. Ontanario: The Centre for International Governance Innovation, 2010.

17. Šulović V, BCSP. Meaning of Security and Theory of Securitization. Belgrade Centre for Security Policy, 2010.

18. Vial V, Hanoteau J. Corruption, Manufacturing Plant Growth, and the Asian Paradox: Indonesian Evidence. World Development. 2009; 38(5):693-705. 2010. Elsevier Ltd. Doi: 10.1016/j.worlddev.2009.11.022

19. Williams CM. Words, Images, Enemies: Securitization and International Politics. International Studies Quarterly USA and UK, Blackwell Publishing. 2003;
47:511-531

20. Wolfers A. 'National Security' as Ambiguous Symbol. JSTOR: Political Science Quarterly. 1952; 67:4481502.

21. Žilović M. The Concept of Political and Future of the Copenhagen School of Security Studies. Journal of the Belgrade School of Security Studies. Western Balkans Security Observer. Carl Schmitt and Copenhagen School of Security Studies, No 13. UDK. 2009; 327(56):351-86|:141.7; 321.01:141.7. Center for CivilMilitary Relations 